\title{
Gender Identity Disorders: Current Medical and Social Paradigm and the ICD-11 Innovations
}

\author{
Расстройства половой идентификации: современная медико-социальная \\ парадигма и инновации МКБ-11 \\ doi:10.17816/CP68
}

\author{
(C) Anton V. Dyachenko ${ }^{1,2}$, Alexey Y. Perekhov ${ }^{2}$, \\ Victor A. Soldatkin², Olga A. Bukhanovskaya ${ }^{1,2}$ \\ 'The Medical and Rehabilitation Research center «PHOENIX», \\ Rostov-on-Don, Russia; ${ }^{2}$ Department of psychiatry, narcology \\ and medical psychology, Rostov State Medical University, \\ Rostov-on-Don, Russia
}

\author{
(C) Антон В. Дьяченко 1,2, Алексей Я. Перехов², \\ Виктор А. Солдаткин ${ }^{2}$, Ольга А. Бухановская ${ }^{1,2}$ \\ 'Лечебно-реабилитационный научный чентр \\ "ФЕНИКС», Ростов-на-Дону, Россия; ${ }^{2}$ Кафедра \\ психиатрии, наркологии и медицинской психологии, \\ Ростовский государственный медицинский \\ университет, Ростов-на-Дону, Россия
}

\begin{abstract}
Introduction. This article presents a review of current concepts of gender identity under normal and pathological conditions.
\end{abstract}

Aim. To analyse the impact of the medical and social paradigm shift for clinical practice.

Results and discussion. The modern academic literature devoted to gender identity disorders is characterized by a variety of terminology, a shift in emphasis from clinical judgement to a socially beneficial normocentric approach and a relatively few advanced, evidence-based research. There is also a lack of evidence for the gender theory underlying the new approach, which raises serious doubts about the validity of the medical and social paradigm revision. In the same time, the position of Russian psychiatrists remains to be more clinically oriented.

Conclusion. Patients who declare the desire to reassign their gender have to be assessed by psychiatrists for differential diagnosis to exclude a mental disorder. In such cases, the destigmatization of mental disorders is more critical than the depathologization of gender identity disorders.

\section{АННОТАЦИЯ}

Введение. В данной статье представлен обзор научной литературы, посвященной современным представлениям о половой идентификации в норме и патологии.

Цель исследования. Проанализировать значение смены медико-социальной парадигмы для клинической практики.

Результаты и обсухдение. Современная научная литература, посвященная расстройствам половой идентификации, характеризуется терминологическим многообразием, смещением акцентов с клинической оценки данного феномена к социально-ориентированному нормоцентрическому подходу и относительно 
низким доказательным уровнем исследовательских работ. Гендерная теория, лежащая в основе нового подхода, до сих пор не нашла научно аргументированного подкрепления. Это обстоятельство вызывает серьезные сомнения в обоснованности произошедшего пересмотра медико-социальной парадигмы. На этом фоне позиция российских психиатров представляется более клинически ориентированной.

Выводы. Пациенты, заявляющие о желании изменить пол, нуждаются в тщательной псхиатрической дифференциальной диагностике с исключением психических расстройств. При этом дестигматизация психических расстройств оказывается важнее депатологизации расстройств половой идентификации.

Keywords: gender identity disorders; gender dysphoria; transsexualism; transgender; gender reassignment Ключевые слова: расстройства половой идентификации; гендерная дисфория; транссексуализм; трансгендер; изменение пола

\section{INTRODUCTION}

Clinical features, mechanisms of development and methods of correction of gender identity disorders (GIDs) were described in detail in the academic literature of the second half of the twentieth century. The vision of gender-role deviations in human behaviour as a diverse group of mental disorders was formed. These included both congenital and persistent anomalies, and clinically similar but aetiologically variable courses and prognoses of medical conditions. ${ }^{1,2}$ However, the revision of the scientific paradigm, the contradictions that have arisen in the medical community and the unprecedented increase in the number of requests for gender reassignment in many countries, ${ }^{3-5}$ mean that further research is needed in this field.

The purposes of the present study are to provide a review of current concepts of gender identity under normal and at pathological conditions, and to analyse the impact of the medical and social paradigm shift for clinical practice. The study involved an information search of the Medline academic database and eLibrary in English and Russian, respectively, using the keywords 'gender identity disorders', 'gender dysphoria', 'transness' and 'gender reassignment'. The search identified 164 publications. Of these, 49 publications devoted to the psychologicalpsychiatric and socio-legal aspects of the problem of GIDs were selected for a content-related analysis. In total, 55 literary sources were used for citation.

In contemporary science, the study of GID is conducted mainly within the framework of 'gender studies', related to the humanities (psychology, sociology, philosophy, etc.). Published meta-analyses have indicated that the information obtained from the field of gender studies is not unambiguous. ${ }^{6-11}$ According to P. W. Hruz et al. (2020), the shortcomings in the current understanding of GID include the limited amount of existing academic literature, the lack of randomized follow-up studies, small sample sizes, imperfect eligibility criteria, short duration of studies, high percentages of discontinued patients and dependence on the opinion of experts. ${ }^{11}$

\section{PREVALENCE OF GIDS}

According to the meta-analysis of J. Arcelus (2015), the prevalence of transsexualism is 4.6 people per 100,000 population; 6.8 for trans women and 2.6 for trans men. There has been an increase in registered prevalence over the past 50 years. ${ }^{12}$

In the systematic review of L. Collin (2016), which covered 27 publications, the incidence of transgender people in medical institutions for hormonal and surgical treatment was 9.2 people per 100,000 population. However, the authors specified an appreciable variation in the data in particular studies. ${ }^{13}$

The prevalence of GID among present-day young people is about $1 \% .^{12-14} \mathrm{~K}$. J. Zucker quotes similar figures (from $0.5 \%$ to $1.3 \%$ ), but with the essential clarification that there is a significantly higher occurrence of GID among children and adolescents compared to adults. ${ }^{17}$ This is consistent with data showing that $70-94 \%$ of minors who express dissatisfaction with their gender subsequently refuse to perform trans role self-introduction..$^{18-20}$

\section{GID CLINICAL MANIFESTATION}

Current data on GID clinical manifestation are very ambiguous. ${ }^{20-22}$ They describe GIDs that are congenital and relatively stable conditions, which develop in parallel 
with psychosexual maturation and variants that are characterized by 'rapid' occurrence. Patients may identify themselves inversely with respect to gender, or identify as being outside of the binary gender-role model. Inverse identification is probably more common than nonbinary identification. Some patients reject the external characteristics of gender and want to remove them, while others do not experience significant discomfort. In some cases, self-identification, gender-role behaviour, sexual orientation and external attributes correspond with one other, but in others they are inconsistent.

Gender dysphoria, i.e., a state of psychological distress caused by the rejection of one's biological gender and gender-role status, is singled out as the basic clinical phenomenon that determines the treatment for psychological and psychiatric support. Gender dysphoria may be both endopsychic, expressed through pressing emotional experiences (depression, anxiety, internal conflicts, etc.) and exopsychic, expressed through behavioural disorders (addiction, auto-destruction, proneness to conflict, self-isolation, etc.). ${ }^{17,20}$ The overwhelming majority of studies indicate a high prevalence of mental disorders in individuals with GID, including high suicide risk. ${ }^{20,23}$ Numerous data on the susceptibility of children with gender-role disorders towards self-stigmatization, depression, eating disorders, alcoholism, drug addiction, self-mutilation and suicidal behaviour are presented. L. Nahata et al. (2018) analysed 79 medical records of patients aged nine to 18 years referred to the paediatric endocrinology department in connection with GID. The vast majority (92.4\%) were diagnosed with at least one of the following nosological entities: depressive disorder, anxiety disorder, posttraumatic stress disorder, eating disorders, autism spectrum disorder or bipolar affective disorder; $74.7 \%$ reported suicidal ideation; $30.4 \%$ made one or more suicide attempts; $55.7 \%$ confirmed self-mutilation. ${ }^{24}$

R. B. Toomey et al. (2018) surveyed 120,617 adolescents with GID between the ages of 11 and 19 . $14 \%$ of respondents reported making a suicide attempt in the past. Suicidal behaviour was most typical for girls seeking to reverse transformation (50.8\%), as well as for adolescents of both genders with non-binary positioning (41.8\%). ${ }^{25}$ A survey of 923 young Canadians who identify as transgender found that $65 \%$ of respondents aged 14 to 18 had seriously considered suicide within the past year, compared to $13 \%$ in the control group. In this case, young men showed a greater tendency towards selfmutilation and suicide. ${ }^{26}$

L. A. Taliaferro et al. (2019) studied the phenomenon of auto-destruction in adolescents with GID by comparing a group of individuals with and without selfmutilations. Of the 1,635 respondents, more than half $(51.6 \%)$ reported episodes of self-mutilation during the past year. Children with auto-destructive behaviour were significantly more likely to report mental health problems, depression, episodes of running away from home and substance use. ${ }^{27}$

The systematic review of L. D. DeFreitas (2020) indicated that, on average, $53.2 \%$ of transgender people have at least one mental disorder in the course of their lifetime. Affective disorders (42.1\%), anxiety disorders (26.8\%) and substance use or substance abuse disorders $(14.7 \%)$ were most frequently identified. ${ }^{28}$

\section{SOCIAL PREMISES AND CONSEQUENCES OF GID DEPATHOLOGIZATION}

Gender theory, conceptually related to feminism, social constructivism, transhumanism and postmodernism, has served as the ideological basis for expanding the boundaries of acceptability in relation to gender-role behaviour. It determines gender identity exclusively by upbringing, gender-role behaviour stereotypes accepted in the macro-and micro-social environment, and personality choice. ${ }^{29}$ The mechanisms of GID occurrence within the framework of gender theory are explained inconsistently. Without denying the results of earlier studies on the biological nature of GID in transgender people, the new concept asserts the freedom of gender-role positioning for all people. In accordance with this, on the one hand, the right to choose self-identification is asserted, on the other hand, it is said that the identity of transgender people is irrefutable, which makes it necessary to create specific conditions for them to adapt. Proclaiming absolute freedom to choose a model of gender-role behaviour, gender theory devalues the motives of this behaviour and unites all the GID versions into a group of 'transgender' (gender nonconforming people, trans minorities, etc.), regardless of their nature, stability, phenomenology, dynamics of development and timing at which their development occurred. ${ }^{13,20}$ Along with transsexuals, transgender people include people with transvestism, some homosexuals and nonconformists who consciously 
demonstrate their commitment to liberal values and the ideology of transhumanism by rejecting socially acceptable gender-role stereotypes.

Following the idea of freedom of self-positioning, attempts to study the factors of susceptibility to 'transness' become meaningless. Perhaps for this reason, there are few such works in the contemporary academic literature. It is believed that people with autism spectrum disorders are more likely to be transgender, ${ }^{30-32}$ but the nature of the relationship between these conditions is not substantiated. The results of the study of genetic, neuromorphological and neuroendocrine factors are rare and less informative. ${ }^{33-35}$

\section{Socio-political and legal effects}

The increase in the number of people seeking to positioning themselves outside of gender may be explained by higher patient referrals against the background of increased availability of medical and psychological care ${ }^{3}$ and a fundamental change in the social paradigm in relation to GID. ${ }^{36}$

The principles for the application of international human rights law in relation to sexual orientation and gender identity were adopted by a group of relevant experts on 6-9 November 2006, in Yogyakarta (Indonesia); these are now known as the Yogyakarta Principles. ${ }^{36}$ The review group included experts on human rights issues of various profiles from different regions, including judges, scientists, a former United Nations (UN) High Commissioner for Human Rights, Special Rapporteurs of the Commission of Human Rights, members of the human rights treaty bodies and representatives of independent human rights organizations. According to the Yogyakarta Principles, countries should include the principle of universality in their national constitutions and legislation, and should implement educational and awareness-building campaigns aimed at ensuring the full enjoyment of all rights and freedoms for all persons, regardless of their gender identity. Sufficient attention is directed to the right to equality and non-discrimination: "everyone is entitled to enjoy all human rights without discrimination on the basis of sexual orientation or gender identity". ${ }^{36}$

In the UN Declaration on Sexual Orientation and Gender Identity, dated 18 December 2008, non-binary gender-role positioning was ranked as a human right that requires protection. The UN member states were requested to take legislative and administrative measures "to ensure that sexual orientation or gender identity may under no circumstances be the basis for arrest or detention....and that human rights violations based on sexual orientation or gender identity are investigated and the perpetrators are brought to responsibility and committed to court." ${ }^{16}$ This document was signed by 96 of the 193 UN member states, including all the states of the European Union, the United States, Canada and Japan.

In a report from 2009, The Council of Europe Commissioner for Human Rights recommended that states 'train medical professionals, including psychologists, psychiatrists and therapists, considering the needs of transgender people and the requirements for respect for their dignity'; "ensure that body correction procedures, such as hormone therapy, surgery and psychological support, are accessible to transgender people, and ensure that these costs are compensated under the state health insurance system." ${ }^{\text {"36 }}$

\section{Exposure of individuals with GID}

\section{to discrimination and violence}

In 2013, the UN unveiled campaign "Free and Equal ", which aimed to protect gay, lesbian, bisexual and transgender people from discrimination. ${ }^{36}$ Concurrently, the causes of gender dysphoria stipulating the treatment of 'transgender' people in medical institutions, within the framework of this approach, are usually associated with the inability of an individual to openly identify in the desired way and implement appropriate genderrole behaviour in the conditions of social pressure (discrimination, transphobia, etc.). A statement from the American Psychiatric Association (2012) stated: "Transness or gender diversity does not imply a deterioration in judgment, stability, reliability, general social or professional abilities; however, these individuals are often discriminated against due to a lack of civil rights protection for their gender identity or self-expression.... Such discrimination and lack of equal civil rights harm the mental health of transgender people and gender-diverse individuals". ${ }^{37}$ The meta-analysis of S. M. Peitzmeier (2020), which included 85 publications $(49,966$ participants), showed that compared with cisgender people, transgender people are 2.2 times more likely to be subjected to physical violence and 2.5 times more likely to be subjected to sexual harassment. ${ }^{38}$ 
The vulnerability of transgender people to discrimination and aggression is also emphasized in the scientific literature. G. R. Murchison et al. (2019) analysed data obtained from 3,673 American adolescents with GID: $26.5 \%$ of girls and $18.5 \%$ of boys with reverse identity, and $27 \%$ of girls and $17.6 \%$ of boys with non-binary positioning, reported cases of sexual violence in the past 12 months. ${ }^{39}$ Considerable attention is paid to the 'insufficient cultural awareness' of medical professionals regarding the current regulations of gender-role behaviour, which prevent young people with GID from receiving assistance. ${ }^{20,39}$ Cases of denial of services, manifestations of rudeness, verbal and physical violence in medical institutions in relation to minors with gender-role disorders are reported. ${ }^{40}$ There is evidence that young transgender people are often subjected to violence by both peers and family members. In the study of K. Peng et al. (2019) of 385 adolescents with GID, 295 (76.6\%) reported being abused or bullied at school by classmates or teachers due to deviant gender-role positioning. Of the 319 respondents who revealed their experiences to their parents, 296 (92.8\%) were subjected to neglect or violence within the family. ${ }^{40}$ In general, the rejection of transgender identification by the immediate environment, the opposition to the desire of patients to the desired self-introduction is emphasized as one of the main sources of gender dysphoria.

\section{The family"s attitude to minor children with GID}

Overcoming parental 'prejudice' is considered to be one of the most essential components for suicide prevention among children with GID. ${ }^{13}$ According to R. Travers et al. (2012), who surveyed 433 transgender adolescents, $4 \%$ of those whose parents supported them had attempted suicide, compared to $60 \%$ of those whose parents did not support them. ${ }^{41}$ Many modern experts favour granting transgender children the full right to self-identification, regardless of the opinion of legal representatives. ${ }^{41}$ In some countries, monitoring of the right of minors to 'gender expression' is executed by public services: the employees of general education and medical institutions, the police and social workers. A striking example of this practice is the Norwegian 'Barnevernet' state service for assistance and support for children and adolescents, which has broad powers up to the deprivation of parental custody.
Under these circumstances, it seems paradoxical that there is an extremely small amount of academic studies exploring the problem of GID in minors from the perspective of parents. In the course of a study conducted in 2018 at Brown University (USA), 256 questionnaires of parents for children with 'rapid' development of GID were analysed. Adolescents (the average age at the time of the study was 16.4 years) reported their 'transgender identification' on average at the age of 15 . Some $41 \%$ expressed a non-heterosexual orientation before they began to identify as transgender; $62.5 \%$ were diagnosed with at least one psychogenic disorder or nervous system disturbance of development prior to complaining of gender dysphoria. The number of established diagnoses varied from one to seven. Nearly half (47.2\%) of children reported a psychologic decline in mental health to their parents. More than half (57.3\%) noted a deterioration in the attitude of other children towards them. Other behavioural changes were also observed, including expression of distrust towards nontransgender people (22.7\%), refusal to spend time with non-transgender friends $(25.0 \%)$, desire to be isolated from family members (49.4\%) and significant trust related to information about GID that is received from 'transgender' sources (46.6\%). The majority (86.7\%) of parents reported that, along with the sudden or rapid occurrence of GID, their child either spent more time on the Internet and social networks, or socialized in a group where one or more friends has become transgender. ${ }^{21}$

\section{DIAGNOSIS OF GID IN ICD-11}

In accordance with the new social paradigm in current medicine, approaches to the diagnosis of GIDs have been radically modified. According to the official position of the World Health Organization (WHO), gender identity itself is not the subject of psychiatric analysis and, like political or religious beliefs, should be considered exclusively in the context of civil liberties and individual psychological diversion. ${ }^{36}$ The conditions identified in the International Classification of Diseases 11th Revision (ICD-11) as 'gender incongruence', which replaced 'gender identity disorders', are found in Chapter 17 (in the section 'Conditions related to sexual health'). This new grouping includes three categories: gender incongruence of adolescence or adulthood (HA60); gender incongruence in childhood (HA61); and gender incongruence, unspecified (HA6Z). ${ }^{42}$ Gender incongruence 
of adolescence and adulthood is described as a marked and persistent incongruence between an individual's experienced gender and the assigned sex, which often leads to a desire to 'transition', in order to live and be accepted as a person of the experienced gender, through hormonal treatment, surgery or other health care services to make the individual's body align, as much as desired and to the extent possible, with the experienced gender. Gender incongruence of childhood is characterized by a marked incongruence between an individual's experienced/expressed gender and the assigned sex in pre-pubertal children. It includes a strong desire to be a different gender than the assigned sex; a strong dislike on the child's part of his or her sexual anatomy or anticipated secondary sex characteristics and/or a strong desire for the primary and/or anticipated secondary sex characteristics that match the experienced gender; and makebelieve or fantasy play, toys, games, or activities and playmates that are typical of the experienced gender rather than the assigned sex. The incongruence must have persisted for about two years. ${ }^{42}$

\section{IMPACT OF MEDICAL INTERVENTIONS FOR GENDER REASSIGNMENT ON THE MENTAL WELLBEING OF INDIVIDUALS WITH GID}

In the context of earlier requests for gender reassignment, the issue of aiding minors is actively discussed. The American Psychological Association (APA) and the American Academy of Paediatrics (AAP) have proposed a 'gender-affirmative care model'. This approach, which is focused on "understanding and evaluating the gender experience, unbiased partnership with young people and their families", proclaims the following:

1. Transgender identity and diverse gender expressions do not constitute a mental disorder.

2. Variations in gender identity and expression are normal aspects of human diversity and binary definitions of gender do not always reflect emerging gender identities.

3. Gender identity evolves as an interplay of biology, development, socialization and culture.

4. If a mental health issue exists, it most often stems from stigma and negative experiences rather than being intrinsic to the child. ${ }^{37}$
In a number of countries, the issue of reducing agerelated contraindications for medical interventions for gender reassignment is being discussed. Among other measures, this refers to the possibility of conducting hormonal replacement therapy for people who have not reached puberty age..$^{43,44}$ Various public organizations that take a stand in favour of the liberalization of indications for gender reassignment argue that the age of medical intervention should depend on the treatment reversibility level. According to this proposal, hormonal blockade, considered 'reversible' by the World Professional Association for Transgender Health, can be performed with children as young as nine years old, while procedures that are considered 'irreversible', such as genital surgery, should be restricted to adults. ${ }^{20}$ Some authors insist on the need to approve the right to perform hormonal blocking of puberty without parental consent. ${ }^{44}$

A large amount of data has been published in support of the statement that the implementation of gender reassignment measures contributes to improving adaptation and reducing the indicators of anxiety, depression and suicidal risk in children., ${ }^{8,14,15}$ In general, most research shows a high level of satisfaction among individuals with GID without clinical differentiation performed by transformation. ${ }^{9}$ However, there are also procedurally similar frameworks that demonstrate negative results. S. L. Reisner et al. (2015) conducted a retrospective cohort study of the medical records of 180 patients with GID aged 12 to 29 years, examined between 2002 and 2011 at a hospital in Boston (USA). People with GID reported depression, anxiety, autodestructive experiences and experience of inpatient and outpatient psychiatric treatment two to three times more than the group of people not experiencing genderrole disorders. However, there were no statistically significant differences in the results of assessing mental health indicators when comparing patients of different genders, when correcting for age, ethnicity and hormonal medication use. ${ }^{12}$ It is noteworthy that, despite the unprecedented liberalization of gender-role behaviour in a number of countries, suicide rates among people with GID remain extremely high, at 50-93\%. ${ }^{20,23}$

\section{VIEWS OF RUSSIAN CLINICIANS}

The scientific validity of the modifications that have taken place in the approaches to the systematics, diagnosis and therapy of GID have raised doubts among a significant 
body of Russian specialists. G. E. Vvedenskiy and S. N. Matevosyan (2017), analysing the modification in the approach to the diagnosis of GID in the ICD11, stated the following: "...the proposals of the Work Group to change the categories of gender disorders in the ICD-11 are largely based on the social consequences of diseases and "legal considerations" in a subjective ideological interpretation when trying to ignore clinical psychopathological phenomenology and a pronounced tendency to depathologize it, that will negatively affect the possibility of using the classification in the work of practising psychiatrists and sexologists". ${ }^{45}$ N. D. Kibrik and M. I. Yagubov (2018) stated a similar forewarning: "...such depathologization of the individuals who desire to assign their gender can lead to serious consequences, since the fact that this condition can often be combined with mental disorders or be their manifestation, as well as contain an obvious or potential risk of suicide is not considered". ${ }^{46}$

In Russian sexology, the perception of the human sex as a three-dimensional structure, including the biological component and social and mental determinants, has been strengthened. ${ }^{1,47}$

Sociocultural segregation of sex (social gender) manifests itself in various spheres of social interaction, including civil law, morals and ethics, material and household concerns, pedagogy, professional, religion, sexual, language, behaviour style and appearance. ${ }^{47}$ Social gender has a connection with the cultural environment and therefore there is a range of evidence in different countries and in different time periods.

Mental sex dimorphism (mental gender) is represented by a complex arrangement of mental and behavioural properties which distinguish men from women. At the subjective level, mental gender forms the feeling of identity with one of the genders that is characteristic of most people, the consciousness of one's 'Self' as a man or woman, the awareness of gender-related personality traits and the desire to regulate gender-role behaviour in accordance with the perceived gender. This phenomenon was defined as gender self-awareness by G. S. Vasilchenko. ${ }^{47}$ In more contemporary literature, the term 'gender identity' is used in a similar sense. ${ }^{48-50}$ The character of this phenomenon remains understudied. It is considered to be a complex mental structure, determined by both biological and social effects, including innate and acquired, and stable and variable parameters. According to Russian scientists, gender self-awareness, potentials and abilities of the individual involved in the establishment of gender-role behaviour, as well as physical gender characteristics, are biologically determined., ${ }^{1,2}$ Thus, in the case of mental gender congruence to the chromosome set, we should speak of a 'standard' gender identity and for incongruence, we should speak of a 'gender identity disorder (violation)'. The latter can be congenital, due to hypothetical intrauterine effects during the sexual differentiation of the foetal brain, or acquired, arising under the impact of social conditions, individual personality characteristics or mental disorder.

\section{Views on transsexualism in Russian psychiatry}

Asserting the coincidence of sex and gender identity as a standard, within the framework of the approach shared by Russian psychiatrists, it is proposed to distinguish two large groups of GID: stable mental anomalies and dynamic disorders. ${ }^{2}$ The group of stable mental anomalies includes a single condition - transsexualism. As a pathognomonic feature, it is distinguished by an innate and persistent inversion of gender identity, accompanied by the rejection of corresponding genotype gender characters, the desire to assimilate in society among persons of the opposite gender, as well as the desire to transform physical appearance and social status in the image of representatives of the opposite gender.

There are no official statistics on the prevalence of transsexualism in Russia, but this state is considered to be very rare and the number of people experiencing it is relatively stable. According to S. N. Matevosyan et al. (2008), the number of referrals to specialized institutions that provide assistance to persons with GIDs is on average about 60 per year (gender ratio 1:1), of which the diagnosis of 'transsexualism' is established in $52.5 \%$ of cases among men and $69.2 \%$ of cases among women. ${ }^{51}$

Based on the data that transsexualism occurs in all ethnic groups, in different cultures and does not depend on education, financial security or psychosexual upbringing, ${ }^{1,2}$ most researchers tend to believe that it is mainly based on biological factors associated with a violation of sexual differentiation of the brain under the abnormal effect of foetal androgens. ${ }^{52-54}$ The result of this disorder is, according to some authors, the 
'inverse' formation of a number of brain structures, primarily the hypothalamus. ${ }^{1,52}$

Clinical manifestations of transsexualism arise from the basic characteristic of this state innate and persistent inversion of gender identity. Depending on the severity of gender-role disorders, two variants of transsexualism are distinguished, nuclear and acentric. ${ }^{1,2}$

Nuclear transsexualism manifests itself from early childhood (up to five years of age) with behavioural disorders caused by a sense of belonging to the opposite gender. The social environment has almost no effect on the formation of gender-role behaviour. Further psychosexual development occurs in accordance with stereotypical characteristics of the opposite gender, accompanied by a difficult experience of the occurrence of secondary gender characters in puberty and incessant attempts to correct the appearance so that it has maximum similarity with the representatives of the opposite gender. The sexual behaviour of nuclear transgender people is exclusively homosexual in relation to the biological gender. Socialization is dilemmatic, due to the active desire of transsexuals to adapt in society exclusively in the desired field: their appearance, lifestyle, professional activities and habits are subordinated to the gender-role stereotypes accepted in society that relate to the opposite gender.

Acentric transsexuals are described as characterized by a higher ability to self-control gender-role behaviour under the influence of micro-social conditions, which in some cases gives the impression of 'standard' gender-role behaviour and sufficient social adaptation. In these cases, violations of gender-role stereotypes are observed from childhood, which, however, are suppressed by the micro-community. The inverse libido is also suppressed because of the individual's commitment to social standards. In some cases, acentric transgender people may maintain heterosexual relationships, but these may not be harmonious and satisfying. Compensation and adaptation are based only on the self-control of patients and their incessant internal struggle with the inverse self-consciousness, which leads to disharmony of the personality and its pathocharacterological formation. A. O. Bukhanovskiy distinguished two groups of symptoms of transsexualism, which are in hierarchical subordination: the basic (main) and derived. ${ }^{2}$
The basic symptoms include:

- Inversion of gender identity: identification of oneself as a person of the opposite gender while maintaining a rational assessment and understanding of both biological and social sex.

- Inversion of sexual socialization of the individual: the assimilation, often exaggerated, by the patient of personal and psychological qualities (temperamental attributes and orientation of the individual, value orientations, worldview, moral and ethical standards, family and professional aspirations, habits, behavioural characteristics), which are considered characteristic of persons of the opposite gender in the socio-cultural environment of transgender people.

- Inversion of psychosexual identity: homosexuality, the orientation of erotic and sexual libido exclusively to heterosexual same-sex partners, the desire to perform an inverse sexual role in sexual relationship.

- The derived symptoms of transsexualism include:

- The symptom of gender rejection is a feeling of discontent, reaching the point of hatred, for the gender characteristics of one's body and for the manifestations of their functioning.

- Multiple presentations of psychosocial maladjustment.

- Auto-destructive behaviour, including suicidal.

- Transsexual attitudes to the gender reassignment take on various intensities (from fantasies to unambiguously expressed decisions about the need to reassign the gender):

- Experiences that devalue the genitals are phenomenologically close to the symptom of gender rejection.

- Passive thoughts and ideas about one's own sexual life in the absence of a goal-setting intention to achieve a real transformation.

- Transgender intentions: the gradual formulation and justification of the idea sexual metamorphosis. This is a fundamentally important stage in the development of the transsexual attitude to gender reassignment, as awareness of the goal appears and a system of evidence is developed.

- The transsexual decision is an attachment to the ideational component of the willing incentive. From this point on, the behaviour starts to resemble the overvalued. 


\section{Sexual transformation in GID}

and similar mental disorders

As a rule, sexual transformation is considered as the only effective way to correct gender dysphoria in transsexualism. ${ }^{2}$ On the one hand, gender reassignment is a method of psychocorrection that allows not only to reduce the risk of suicide, but also to significantly improve the quality of life and psychoemotional state of patients with GID. On the other, it is a set of measures associated with aradical change in the social and legal status of a person, carrying out cardinal and only partially reversible medical interventions, proven effective only in cases of transsexualism. This condition imposes a special responsibility on the doctor: a mistake in this issue is fraught with the most tragic consequences to the patient.

Differential diagnosis is carried out with disorders and conditions in which violations of gender identity and gender-role behaviour can also be observed. Such disorders include ego-dystonic homosexuality, fetishistic transvestism, personality pathology and schizophrenic spectrum disorders. ${ }^{2}$ The gender-role disorders observed in these disorders were designated by A. O. Bukhanovskiy as "states similar to transsexualism".2 Having related clinical manifestations, they are not accompanied by a true violation of identity and, accordingly, are based on completely different motives, due to a psychological crisis or psychopathology. It is the existence of 'similar states' and their significantly greater prevalence in comparison with transsexualism in this approach that explains the high frequency of psychopathology and auto-destructive behaviour among transgender people, the existence of gender-role diversity, cases of incongruity of sexual orientation and gender-role identity.

In recent years, schizophrenia spectrum disorders that occur with gender-role disorders have acquired special medical and social significance. According to our statistics, the number of patients with schizophrenic spectrum disorders who are dissatisfied with their gender has increased dramatically over the past decade. A study at the Phoenix Medical Centre (Rostov-on-Don city, southern Russia; one of the oldest institutions in Russia that provides mental health care to people with GID) demonstrated a 46 -fold increase in the number of patients with schizophrenia-related disorders with complaints of gender dysphoria from 2011-2020, compared to 19912000 and 2001-2010. Apparently, this is due to a change in the cultural environment, an increase in the availability of information and an increase in public interest in the phenomenon of transness. ${ }^{55}$ Patients with schizophrenia spectrum disorders therefore potentially constitute a group of patients most vulnerable to medical errors when implementing the ICD-11 diagnostic requirements. The correction of GIDs in mental disorders similar to transsexualism through gender reassignment measures has no scientific basis in view of the complete lack of data on the positive impact of sexual transformation on the mental disorders course and prognosis.

\section{CONCLUSION}

It should be recognized that the problem of transness has clearly revealed procedural problems in modern psychiatry, especially related to the group of so-called 'behavioural' disorders. The exclusion 'transsexualism' from the new editions of the international medical classifications is arguably justifiable since this phenomenon is not related specifically to 'states related to sexual health' and is not a true mental disorder due to the absence of psychopathology. However, this health condition was diagnosed earlier and procedurally should have been diagnosed further by psychiatrists, who, due to their specific knowledge, are able to make a differential diagnosis and distinguish transsexualism from clinically similar but aetiologically variable courses and prognoses of medical conditions. Do not allocating a proper place for transsexualism in the classification system, the ICD-11 developers apparently ignore the very existence of this category that is not a proper decision on our opinion.

The modified diagnostic approaches create new arrangements for psychiatrists to work with patients who request gender reassignment. However, this work still requires a differentiated, ideologically neutral approach. Regardless of the current medical and social paradigm or political standpoint, patients who declare a desire to reassign their gender need a thorough clinical diagnosis to exclude a mental disorder. We believe that the direction of modern psychiatry development should be associated not with the depathologization of some nosological entities, but with the destigmatization of mental disorders. Such attitude seems to be the only promising approach that fully corresponds to the goal of reconciling the two components of the concept of GIDs that are currently disjointed: the socially oriented and the clinically scientific. 
Conflict of interests: Authors declare no conflict of interest.

\section{Correspondence to:}

\section{Anton Dyachenko}

avddoc@yandex.ru

\section{For citation:}

Dyachenko AV, Perekhov AY, Soldatkin VA, Bukhanovskaya OA. Gender identity disorders: current medical and social paradigm and the ICD-11 innovations. Consortium Psychiatricum. 2021;2(2):54-64. doi: 10.17816/CP68

\section{References}

1. Vasil'chenko GS. Seksopatologiya: Spravochnik. Meditsina; 1990.

2. Bukhanovskii AO. Transseksualizm i skhodnye sostoyaniya. Mini Taip; 2016.

3. Skordis N, Butler G, de Vries MC, Main K, Hannema SE. ESPE and PES International Survey of Centers and Clinicians Delivering Specialist Care for Children and Adolescents with Gender Dysphoria. Horm Res Paediatr. 2018;90(5):326-331. doi:10.1159/000496115

4. Fuss J, Auer MK, Briken P. Gender dysphoria in children and adolescents: a review of recent research. Curr Opin Psychiatry. 2015;28(6):430-434. doi:10.1097/YCO.0000000000000203

5. Frisen L, Soder O, Rydelius PA. Dramatic increase of gender dysphoria in youth. Article in Sweden. Lakartidningen. 2017;114.

6. Lambrese J. Suppression of puberty in transgender children. Virtual Mentor. 2010;12(8):645-649. doi:10.1001/ virtualmentor.2010.12.8.jdsc1-1008

7. Priest M. Transgender Children and the Right to Transition: Medical Ethics When Parents Mean Well but Cause Harm. Am J Bioeth. 2019;19(2):45-59. doi:10.1080/15265161.2018.1557276

8. Durwood L, McLaughlin KA, Olson KR. Mental Health and SelfWorth in Socially Transitioned Transgender Youth. J Am Acad Child Adolesc Psychiatry. 2017;56(2):116-123 e112. doi:10.1016/j. jaac.2016.10.016

9. de Vries AL, Steensma TD, Doreleijers TA, Cohen-Kettenis PT. Puberty suppression in adolescents with gender identity disorder: a prospective follow-up study.J Sex Med. 2011;8(8):2276-2283. doi:10.1111/j.1743-6109.2010.01943.x

10. Reisner SL, Deutsch MB, Bhasin S, et al. Advancing methods for US transgender health research. Curr Opin Endocrinol Diabetes Obes. 2016;23(2):198-207. doi:10.1097/MED.0000000000000229

11. Hruz PW. Deficiencies in Scientific Evidence for Medical Management of Gender Dysphoria. Linacre Q. 2020;87(1):34-42. doi:10.1177/0024363919873762

12. Arcelus J, Bouman WP, Van Den Noortgate W, et al. Systematic review and meta-analysis of prevalence studies in transsexualism. Eur Psychiatry. 2015;30(6):807-815. doi:10.1016/j. eurpsy.2015.04.005

13. Collin L, Reisner SL, Tangpricha V, Goodman M. Prevalence of Transgender Depends on the "Case" Definition: A Systematic Review. J Sex Med. 2016;13(4):613-626. doi:10.1016/j. jsxm.2016.02.001

14. Connolly MD, Zervos MJ, Barone CJ, 2nd, Johnson CC, Joseph CL. The Mental Health of Transgender Youth: Advances in
Understanding. J Adolesc Health. 2016;59(5):489-495. doi:10.1016/j. jadohealth.2016.06.012

15. Castilla-Peon MF. Medical management of transgender children and adolescents. Bol Med Hosp Infant Mex. 2018;75(1):7-14. doi:10.24875/BMHIM.M18000003

16. Rafferty J, Committee On Psychosocial Aspects Of C, Family $\mathrm{H}$, et al. Ensuring Comprehensive Care and Support for Transgender and Gender-Diverse Children and Adolescents. Pediatrics. 2018;142(4). doi:10.1542/peds.2018-2162

17. Zucker KJ. Epidemiology of gender dysphoria and transgender identity. Sex Health. 2017;14(5):404-411. doi:10.1071/SH17067

18. Stroumsa D. The state of transgender health care: policy, law, and medical frameworks. Am J Public Health. 2014;104(3):e31-38. doi:10.2105/AJPH.2013.301789

19. Giordano S. Importance of being persistent. Should transgender children be allowed to transition socially? J Med Ethics. 2019;45(10):654-661. doi:10.1136/medethics-2019-105428

20. Standarty pomoshchi transseksualam, transgenderam i genderno nekonformnym individuumam (7-ya versiya). Acceseed April 21, 2021. https://www.wpath.org/publications/soc

21. Littman L. Parent reports of adolescents and young adults perceived to show signs of a rapid onset of gender dysphoria. PLoS One. 2018;13(8):e0202330. doi:10.1371/journal. pone. 0202330

22. Van Donge N, Schvey NA, Roberts TA, Klein DA. Transgender Dependent Adolescents in the U.S. Military Health Care System: Demographics, Treatments Sought, and Health Care Service Utilization. Mil Med. 2019;184(5-6):e447-e454. doi:10.1093/ milmed/usy264

23. Virupaksha HG, Muralidhar D, Ramakrishna J. Suicide and Suicidal Behavior among Transgender Persons. Indian J Psychol Med. 2016;38(6):505-509. doi:10.4103/0253-7176.194908

24. Nahata L, Quinn GP, Caltabellotta NM, Tishelman AC. Mental Health Concerns and Insurance Denials Among Transgender Adolescents. LGBT Health. 2017;4(3):188-193. doi:10.1089/ Igbt.2016.0151

25. Toomey RB, Syvertsen AK, Shramko M. Transgender Adolescent Suicide Behavior. Pediatrics. 2018;142(4). doi:10.1542/peds.20174218

26. Veale JF, Watson RJ, Peter T, Saewyc EM. Mental Health Disparities Among Canadian Transgender Youth. J Adolesc Health. 2017;60(1):44-49. doi:10.1016/j.jadohealth.2016.09.014

27. Taliaferro LA, McMorris BJ, Rider GN, Eisenberg ME. Risk and Protective Factors for Self-Harm in a Population-Based Sample of Transgender Youth. Arch Suicide Res. 2019;23(2):203-221. doi:10.10 80/13811118.2018.1430639

28. de Freitas LD, Leda-Rego G, Bezerra-Filho S, Miranda-Scippa A. Psychiatric disorders in individuals diagnosed with gender dysphoria: A systematic review. Psychiatry Clin Neurosci. 2020;74(2):99-104. doi:10.1111/pcn.12947

29. Vorontsov DV. The current approaches to gender definitions in social psychology. Article in Russian. Vestnik orenburgskogo gosudarstvennogo universiteta. 2002;(8):97-101.

30. Glidden D, Bouman WP, Jones BA, Arcelus J. Gender Dysphoria and Autism Spectrum Disorder: A Systematic Review of the Literature. Sex Med Rev. 2016;4(1):3-14. doi:10.1016/j.sxmr.2015.10.003

31. Thrower E, Bretherton I, Pang KC, Zajac JD, Cheung AS. Prevalence of Autism Spectrum Disorder and Attention-Deficit Hyperactivity Disorder Amongst Individuals with Gender Dysphoria: A Systematic Review. J Autism Dev Disord. 2020;50(3):695-706. doi:10.1007/s10803-019-04298-1 
32. Hisle-Gorman E, Landis CA, Susi A, et al. Gender Dysphoria in Children with Autism Spectrum Disorder. LGBT Health. 2019;6(3):95-100. doi:10.1089/lgbt.2018.0252

33. D'Andrea S, Pallotti F, Senofonte G, et al. Polymorphic CytosineAdenine-Guanine Repeat Length of Androgen Receptor Gene and Gender Incongruence in Trans Women: A Systematic Review and Meta-Analysis of Case-Control Studies. J Sex Med. 2020;17(3):543550. doi:10.1016/j.jsxm.2019.12.010

34. Kreukels BP, Guillamon A. Neuroimaging studies in people with gender incongruence. Int Rev Psychiatry. 2016;28(1):120-128. doi:1 0.3109/09540261.2015.1113163

35. Mueller SC, De Cuypere G, T'Sjoen G. Transgender Research in the 21st Century: A Selective Critical Review From a Neurocognitive Perspective. Am J Psychiatry. 2017;174(12):1155-1162. doi:10.1176/ appi.ajp.2017.17060626

36. Alisievich ES, Nikitina EM. International regulations to protect the rights of transgender people as a vulnerable population. Vestnik rossiiskogo universiteta druzhby narodov. Seriya: yuridicheskie nauki. 2014;(2):332-342.

37. Drescher J, Haller E, American Psychiatric Association Caucus of Lesbian, Gay and Bisexual Psychiatrists. Position Statement on Discrimination Against Transgender and Gender Variant Individuals. American Psychiatric Association; 2012.

38. Peitzmeier SM, Malik M, Kattari SK, et al. Intimate Partner Violence in Transgender Populations: Systematic Review and Meta-analysis of Prevalence and Correlates. Am J Public Health. 2020;110(9):e1e14. doi:10.2105/AJPH.2020.305774

39. Murchison GR, Agenor M, Reisner SL, Watson RJ. School Restroom and Locker Room Restrictions and Sexual Assault Risk Among Transgender Youth. Pediatrics. 2019;143(6). doi:10.1542/ peds.2018-2902

40. Peng K, Zhu X, Gillespie A, et al. Self-reported Rates of Abuse, Neglect, and Bullying Experienced by Transgender and Gender-Nonbinary Adolescents in China. JAMA Netw Open. 2019;2(9):e1911058. doi:10.1001/jamanetworkopen.2019.11058

41. Travers R, Bauer G, Pyne J, Bradley K, Gale L, Papadimitriou M. Impacts of strong parental support for trans youth: A report prepared for Children's Aid Society of Toronto and Delisle Youth Services. Project: Trans PULSE Project (2005-2018). Acceseed April 21, 2021. https://transpulseproject.ca/wp-content/ uploads/2012/10/Impacts-of-Strong-Parental-Support-for-TransYouth-vFINAL.pdf

42. WHO. Acceseed April 21, 2021. https://icd.who.int/ru
43. Lambrese J. Suppression of puberty in transgender children. Virtual Mentor. 2010;12(8):645-649. doi:10.1001/ virtualmentor.2010.12.8.jdsc1-1008

44. Priest M. Transgender Children and the Right to Transition: Medical Ethics When Parents Mean Well but Cause Harm. Am J Bioeth. 2019;19(2):45-59. doi:10.1080/15265161.2018.1557276

45. Vvedensky GE, Matevossyan SN. Sexual disorders in draft icd11: methodological and clinical challenges. Social and clinical psychiatry. 2017;27(3):102-105.

46. Kibrik ND, Yagubov MI. Clinical features of gender identity disorders and patient management. Andrology and Genital Surgery. 2018;19(3):35-41. doi:10.17650/2070-9781-2018-19-3-35-41

47. Bukhanovskii AO, Andreev AS. Strukturno-dinamicheskaya ierarkhiya pola cheloveka. Feniks; 1993.

48. Kulish SB. Gender dysphoria syndrome in males with schizophrenic spectrum disorders. Russian journal of psychiatry. 2009;(4):52-58.

49. Flotskaya NY. Psikhologicheskie osobennosti razvitiya polovoi identichnosti v doshkol'nom vozraste. Vestnik Baltiiskogo federal'nogo universiteta im. I. Kanta. 2011;(3):147-152.

50. Matevosyan SN, Vvedenskii GE. Polovaya disforiya (klinikofenomenologicheskie osobennosti i lechebno-reabilitatsionnye aspekty sindroma «otverganiya» pola). Meditsinskoe informatsionnoe agentstvo; 2012.

51. Matevosyan SN, Tishova YA, Kalinchenko SY, Rudenko LV. Gender identity disorders: history of the problem and prevalence in the Russian Federation. Russian journal of psychiatry. 2008;(3):65-71.

52. Bao AM, Swaab DF. Sexual differentiation of the human brain: relation to gender identity, sexual orientation and neuropsychiatric disorders. Front Neuroendocrinol. 2011;32(2):214226. doi:10.1016/j.yfrne.2011.02.007

53. Guillamon A, Junque C, Gomez-Gil E. A Review of the Status of Brain Structure Research in Transsexualism. Arch Sex Behav. 2016;45(7):1615-1648. doi:10.1007/s10508-016-0768-5

54. Smith ES, Junger J, Derntl B, Habel U. The transsexual brain-A review of findings on the neural basis of transsexualism. Neurosci Biobehav Rev. 2015;59:251-266. doi:10.1016/j. neubiorev.2015.09.008

55. Dyachenko AV, Bukhanovskaya OA, Soldatkin VA, Perekhov AY. Who Submits a Request to the Psychiatrist for a Gender Change: Results of a 30-Year Study. Psikhiatriya. 2020;18(3):32-41. doi:10.30629/2618-6667-2020-18-3-32-41 